\title{
Depositional ice nucleation on NX illite and mixtures of NX illite with organic acids
}

\author{
By \\ Katherine Marie Primm \\ B.S. University of Central Arkansas, 2012
}

A thesis submitted to the Faculty of the Graduate

School of the University of Colorado in partial

fulfillment of the requirement for the degree of

Masters in Science

Department of Chemistry and Biochemistry

2014 
This thesis entitled:

Depositional ice nucleation on NX illite and mixtures of NX illite with organic acids written by Katherine Marie Primm

has been approved for the Department of Chemistry and Biochemistry

\begin{tabular}{l}
\hline (Margaret A. Tolbert) \\
\\
\hline
\end{tabular}

(Raina V. Gough)

Date

The final copy of this thesis has been examined by the signatories, and we find that both the content and the form meet acceptable presentation standards of scholarly wok in the above mentioned discipline. 
Primm, Katherine Marie (M.S., Chemistry)

Depositional ice nucleation on NX illite and mixtures of NX illite with organic acids Thesis directed by Professor Margaret A. Tolbert

Mineral dust particles are known to be efficient ice nuclei (IN) in the atmosphere. Previous work has probed heterogeneous ice nucleation on various laboratory dust samples including Arizona Test Dust, kaolinite, montmorillonite, and illite as atmospheric dust surrogates. However, it has been recently suggested that a new atmospheric dusts surrogate NX illite may be a better representation of atmospheric dust. Here we use a Raman microscope setup to examine the ice-nucleating efficiency of NX illite. We also investigate the effects of an organic coating on the NX illite particles using a mixture of 5 dicarboxylic acids (M5). The ratio of NX illite to M5 is varied in this work from 1:10 to 100:1. Ice nucleation on pure M5 was also studied. It was found that NX illite is a good IN with an $\mathrm{S}_{\text {ice }}$ value of $1.07 \pm 0.01$ at $-47^{\circ} \mathrm{C}$, with a slight increase in $\mathrm{S}_{\text {ice }}$ at lower temperatures. In contrast, pure M5 is a poor IN with an $S_{\text {ice }}$ value of $1.30 \pm 0.02$ at $-40^{\circ} \mathrm{C}$, relatively independent of temperature. However, M5 shows two different ice crystal habits at low and high temperatures, suggesting depositional nucleation at low temperatures and immersion nucleation at high temperatures. In addition, it was found that 1:1 NX illite:M5 by weight is the threshold composition for hindering the icenucleating ability of NX illite. Optical images reveal that at colder temperatures (lower than $-50^{\circ} \mathrm{C}$ ) 1:1 NX illite:M5 mixtures nucleate depositionally, while at warmer temperatures (higher than $-50^{\circ} \mathrm{C}$ ) immersion ice nucleation occurs. Understanding 
laboratory surrogates of atmospheric dust will lead to a more complete understanding of the formation of ice clouds and their effect on the climate. 


\section{CONTENTS}

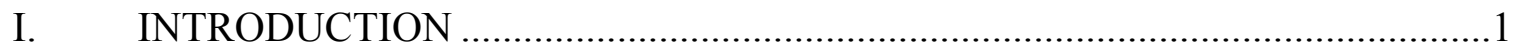

II. EXPERIMENTAL ...................................................................................

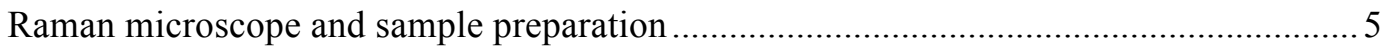

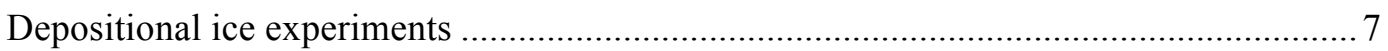

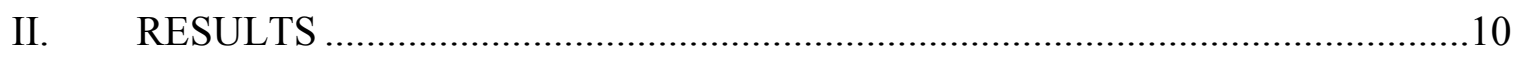

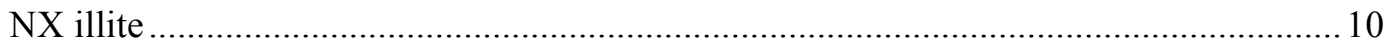

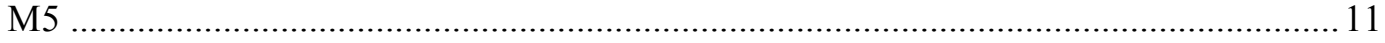

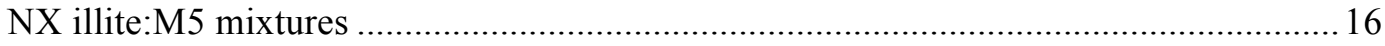

III. CONCLUSION ........................................................................................

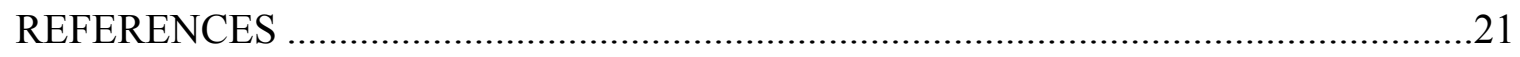




\section{FIGURES}

\section{Figure}

1. Comparison between laboratory dust surrogates and actual atmospheric dust compositions

2. Mineral dust particle, mineral dust with an organic coating, and organic liquid droplet

3. Schematic of Raman Microscope outfitted with environmental (sample) cell ......6

4. Spectral identification of ice on the organic representation (M5) ........................

5. Spectra of different species and mixtures studied ........................................

6. The ice-nucleating ability of NX illite plotted ice saturation ratio vs. temperature

7. Different ice-nucleating regimes of M5 shown in two different regions .............12

8. $\mathrm{RH} /$ Temperature experimental trajectories for M5 ......................................13

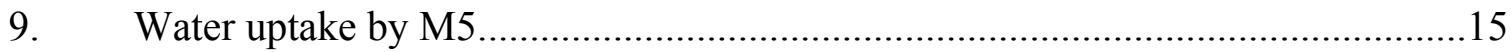

10. A 1:1 NX illite:M5 mixture plotted with pure NX illite and pure M5 ................17

11. Ice nucleation studies of different ratios of NX illite:M5 .................................18 


\section{CHAPTER I \\ INTRODUCTION}

Atmospheric aerosols indirectly impact climate by serving as cloud condensation nuclei and ice nuclei (IN) (IPCC 2013). The indirect effect due to IN is highly uncertain because ice nucleation mechanisms and even ice properties may be highly variable in the atmosphere. Homogeneous ice nucleation occurs when a critical sized germ forms spontaneously in a liquid droplet leading to the whole particle freezing. In contrast, heterogeneous ice nucleation occurs when an aerosol particle lowers the energy barrier for germ formation (Cantrell and Heymsfield, 2005). It is often assumed that homogeneous freezing is the dominant pathway for atmospheric aerosol particles (Koop et al., 2000) because most atmospheric particles are found in the aqueous phase, and the relative humidities in the atmosphere can be well above ice saturation (Froyd and Murphy, 2010). Recently, however, it has been suggested that heterogeneous freezing might be the dominant ice nucleation mechanism in the atmosphere because it can occur at much lower relative humidities and solid seed particles are sufficiently abundant (Cziczo et al. 2013). However, the mechanism and final ice properties for heterogeneous ice nucleation are not well understood (DeMott et al., 2011).

Heterogeneous ice nucleation has multiple different pathways including immersion, condensation, contact, and deposition (Vali 1985; Pruppacher and Klett, 1997). Immersion freezing occurs when a solid aerosol particle is engulfed in an aqueous droplet, inducing ice nucleation. Condensation freezing is similar in that it occurs when 
liquid water condenses onto a particle at water saturation and immediately freezes. Contact freezing occurs when an IN impacts a super-cooled liquid water droplet and freezes. Depositional ice nucleation occurs when an IN serves as the surface of nucleation where vapor can directly deposit to form ice. Depositional ice nucleation is the focus of this study because of its importance in low temperature upper tropospheric ice clouds (DeMott 2002).

In a recent study by Cziczo et al., 2013, it was found that the majority of heterogeneous ice residuals were composed of mineral dust. This is in agreement with earlier work that showed one third of all IN over the western part of North America were composed of mineral dust (Richardson et al., 2007). Clay-mineral substances, such as kaolinite, montmorillonite, and illite, are components of atmospheric dust, with illite being the most abundant of the three (Kumai 1961; Kumai and Francis 1962; Martin 2000; Broadley 2012). For example, mineral dust samples collected in the Caribbean were found to contain $\sim 64 \%$ illite (Glaccum and Prospero 1980), and particulate matter $<2 \mu \mathrm{m}$ (PM 2) collected over the North Pacific was found to be composed of $68 \%$ illite (Arnold 1998). Consequently, NX illite was chosen for this study because has a composition that is close to actual atmospheric dust. Figure 1 is adapted from Broadley et al. (2012) and shows the similarities of NX illite (boxed in red) with actual atmospheric dust (boxed in blue). NX illite, which is rich in illite, consists of $60.5 \%$ illite, $13.8 \%$ illite-smectite, $9.8 \%$ feldspar, $7.2 \%$ kaolinite, $6.6 \%$ quartz, and $2.1 \%$ carbonate (Broadley et al., 2012). Broadley et al. studied immersion ice nucleation on NX illite and the present study probes depositional nucleation at lower temperatures. 


\section{Dust Surrogates Real Atmospheric Dust}

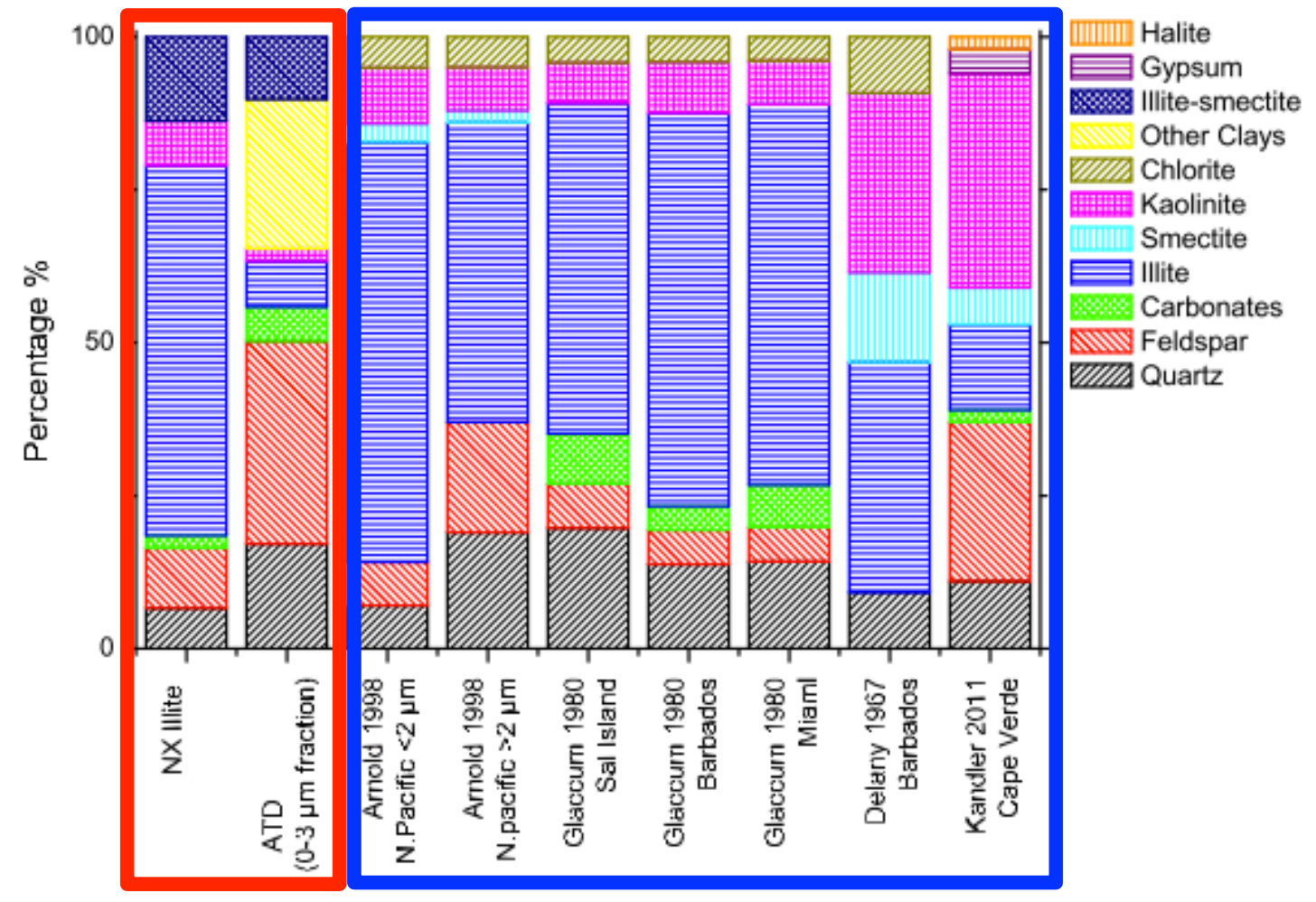

Figure 1. Comparison between laboratory dust surrogates and actual atmospheric dust compositions. This figure shows the different compositions of dust surrogates (boxed in red) compared to actual atmospheric dust compositions (boxed in blue). NX illite proves to be a better representation of actual atmospheric dust compared to Arizona Test Dust (ATD).

In addition to being found as a pure mineral, NX illite is also likely to be coated with, or exposed to, organic compounds (Baustian et al., 2012; Dobson et al., 2000; Ellison et al., 1999). To represent an organic mixture that could come into contact with NX illite, a mixture of 5 different dicarboxylic acids, denoted M5, was used. M5 is composed of malonic, maleic, malic, glutaric, and methyl succinic acids. This mixture has been previously studied for its behavior in the atmosphere (Marcolli et al., 2004; Zobrist and Marcolli, 2008). 
Figure 2 shows the three types of experiments performed in the present study. Past laboratory work suggests that while dust particles are typically excellent IN (Broadley et al., 2012; Bundke et al., 2008; Chernoff and Bertram, 2010; Cziczo et al., 2009; Welti and Lüönd, 2009; Zimmermann et al., 2008), many organics are poor IN (Baustian, 2010; Schill and Tolbert, 2013; Schill et al., 2014). Ice nucleation was measured on both pure NX illite and pure M5 to determine if they behave as other minerals and organics, respectively. Ice nucleation was also probed on mineral dust particles with an organic coating. In the present study, the saturation ratio needed to nucleate ice was determined and the resulting ice crystal was examined to gain insight into the nucleation mechanism.

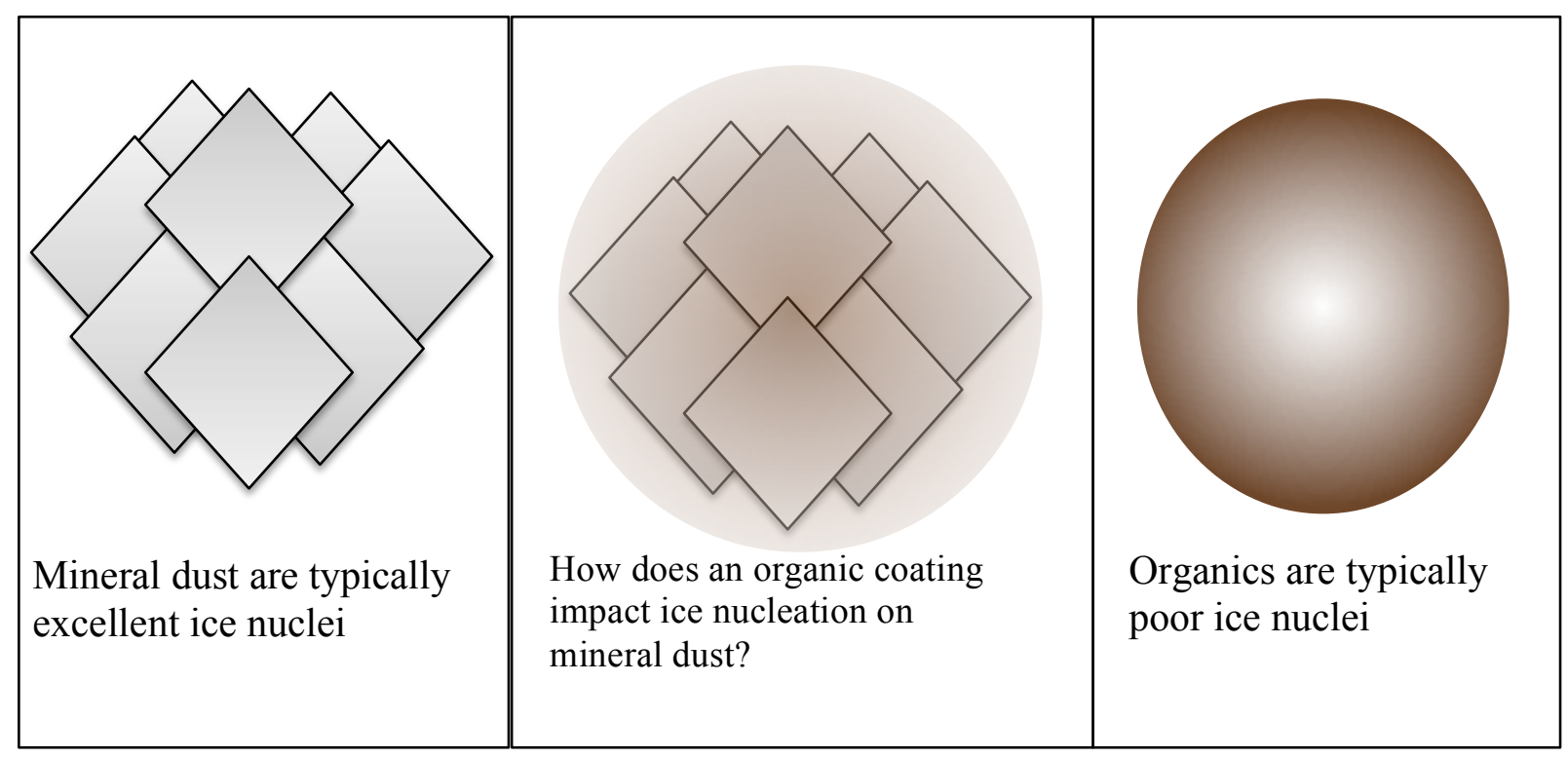

Figure 2. Mineral dust particle (left), mineral dust with an organic coating (middle), and organic liquid droplet (right). Little is known about the effects of an organic coating on the ice-nucleating properties of mineral dust. 


\section{CHAPTER II}

\section{EXPERIMENTAL}

\section{Raman microscope and sample preparation}

Figure 3 shows a schematic of the instrument setup used to study ice nucleation. The experiment uses a Nicolet Almega XR Dispersive Raman spectrometer outfitted with a Linkham THMS600 environmental cell and a Buck Research CR-1A chilled-mirror hygrometer. An Olympus BX51 research-grade optical microscope with 10x, 20x, 50x, and 100x magnification abilities is coupled to the spectrometer. This configuration allows visual and spectral information to be obtained on single particles throughout this study. The experimental setup and the temperature calibration are explained in more detail in Baustian, 2010 and Schill and Tolbert, 2013. 


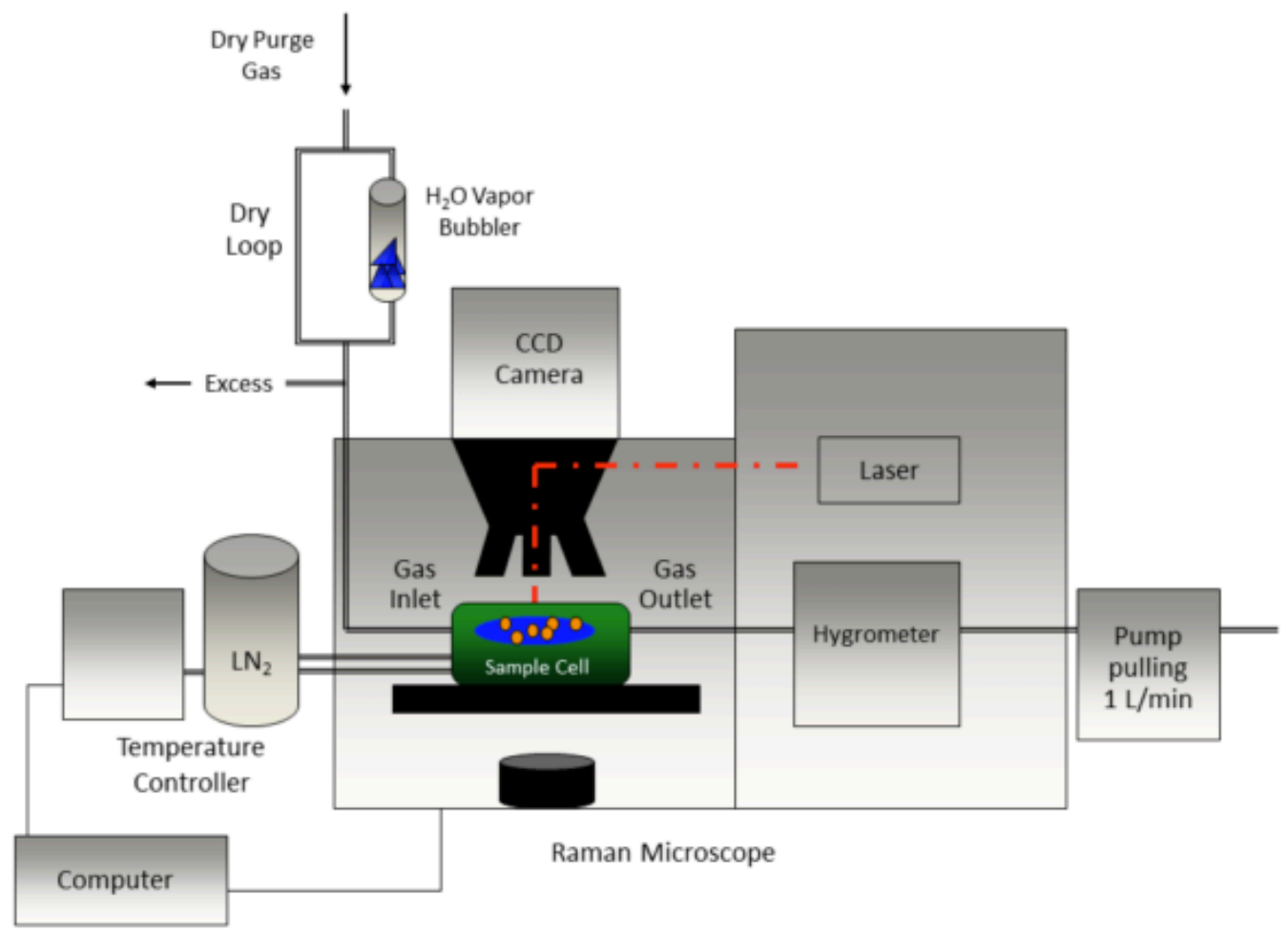

Figure 3. Schematic of Raman Microscope outfitted with environmental (sample) cell. (Baustian, 2010 and Schill and Tolbert, 2013)

Samples are prepared by suspending NX illite in high purity water to a concentration of $0.1 \% \mathrm{NX}$ illite by weight. The M5 mixture is prepared by dissolving the following dicarboxylic acid solids (in their respective weight percents) in high purity water: maleic acid (0.1004\%), malonic acid (0.4017\%), malic acid (0.2498\%), glutaric acid $(0.1999 \%)$, and methylsuccinic acid $(0.0500 \%)$. These are very similar ratios, but not exactly the same, as those of Marcolli 2004. M5 was chosen as the organic mixture because it is a liquid under the conditions explored in this study and because the O:C ratios closely match those found in the atmosphere (Aiken et al., 2008). Ratios of the five dicarboxylic acids are kept constant, but diluted to make the NX illite/M5 mixtures, with 
the NX illite weight percent kept at $0.1 \%$ for each mixture. Ratios of NX illite/M5 range from 1:10 to 100:1 NX illite to M5.

To generate the particles for this study, the solution of interest is aspirated into a Meinhard TR 50 glass concentric nebulizer. The droplets are directed toward a hydrophobically coated-silica disc and placed into a low-humidity-controlled environmental cell to allow the water to evaporate, leaving aggregated dust or dust/organic mixture particles on the disc. Particles ranging from 1 to $30 \mu \mathrm{m}$ in diameter are viewed on the hydrophobically coated fused-silica disc through the Raman microscope.

\section{Depositional ice experiments}

All particles are dried before performing experiments to allow depositional ice nucleation to be probed. A constant flow of water vapor is added to the system by mixing a "wet" $\mathrm{N}_{2}$ flow (dry $\mathrm{N}_{2}$ flowing into a bubbler) with a dry $\mathrm{N}_{2}$ flow before being introduced into the cell. To increase the relative humidity $(\mathrm{RH})$ and ice saturation ratio

$\left(S_{i c e}=\frac{P_{\mathrm{H}_{2} \mathrm{O}}}{V P_{i c e}}\right)$, the temperature is lowered while holding the dew point constant. $S_{\text {ice }}$ refers to the partial pressure of water over the vapor pressure of ice. The temperature is first lowered at the start of an experiment until $\mathrm{S}_{\mathrm{ice}}=0.9$. Once this temperature is reached, the temperature-decrease rate is set to $0.1 \mathrm{~K} / \mathrm{min}$ until ice is identified visually or spectroscopically. It was determined that this rate of temperature decrease would give sufficient time to identify the presence of ice visually, but still be fast enough for the experiment to be performed efficiently. To identify the ice visually, the disc is scanned 
while the temperature is decreased. It takes roughly one minute to scan the disc from left to the right so the largest error in temperature from visual identification of ice is approximately $0.1 \mathrm{~K}$. Once ice is identified, the temperature is held constant and Raman spectroscopy is used to confirm the presence of ice. An example experiment of this process used is shown in Figure 4. The top spectrum shows the Raman spectrum of an ice-containing particle (M5), where the corresponding image is outlined in blue. This image is an M5 particle that has an ice particle deposited onto the side and the spectrum was taken at a position indicated by the red crosshair. The peaks from $3500-3050 \mathrm{~cm}^{-1}$ in the blue spectrum are due to the $\mathrm{OH}$ stretches, indicating ice. The ice is then evaporated and the IN probed again; the image of the particle is outlined in red. The peaks at 2950, 1640,1400 , and below in the red spectrum are $\mathrm{CH}, \mathrm{CO}$, and $\mathrm{COOH}$ stretches due to $\mathrm{M} 5$. From inspecting the two spectra in Figure 4, it is clear that the image outlined in blue contains ice, while the IN outlined in red does not.

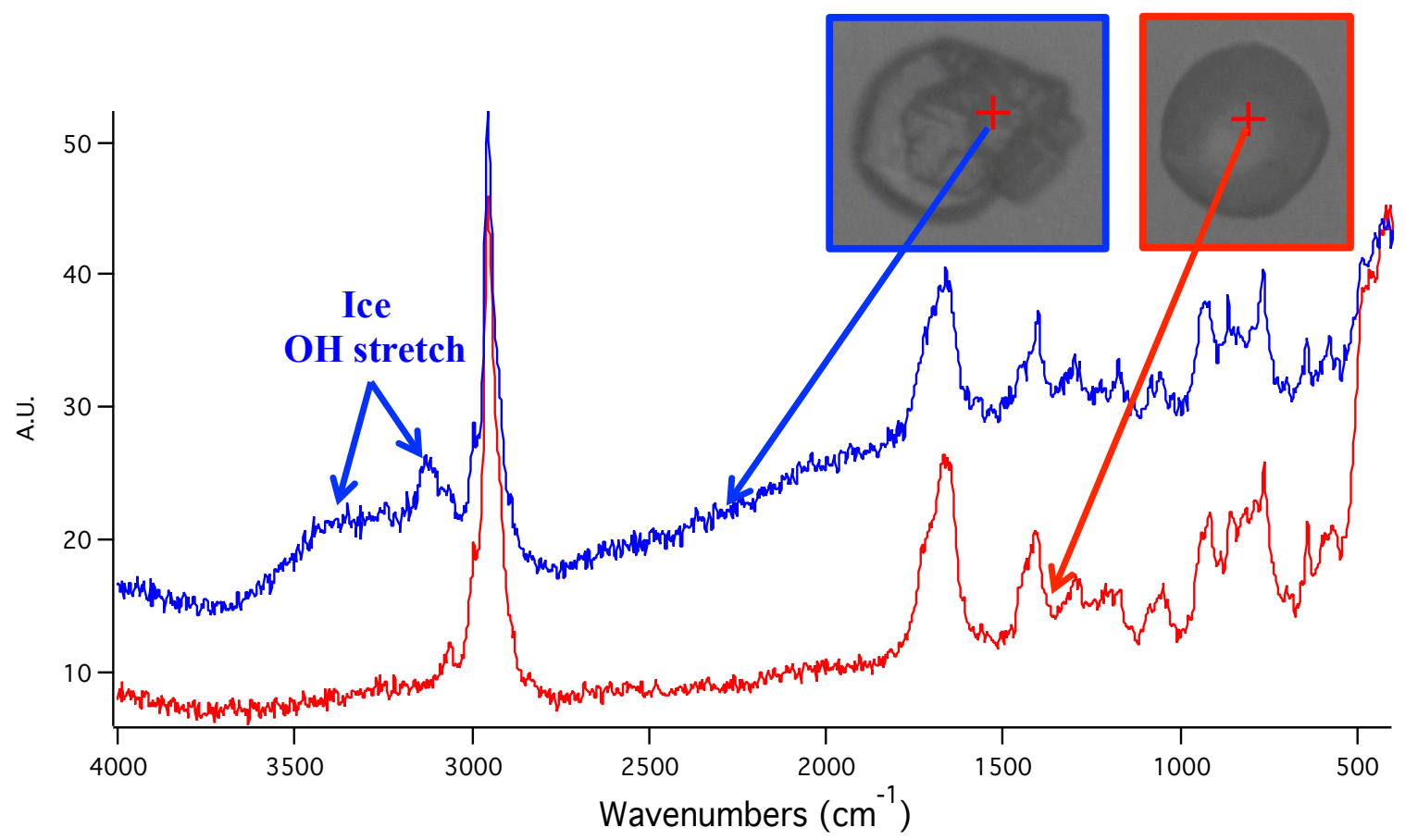

Figure 4. Spectral identification of ice on the organic representation (M5). The image outlined in blue was visually identified having ice, and spectrally from the signature ice Raman-scattering peak $\left(3500-3000 \mathrm{~cm}^{-1}\right)$. The image on the right that is outlined in red is the ice nucleus (IN) of M5 containing no ice. 
Figure 5 shows spectra of NX illite (blue), M5 (red), and the 1:1 NX illite/M5

mixture (black). NX illite is highly fluorescent while M5 is not. Spectral identification of M5 alone is useful, but when NX illite was mixed with M5 Raman spectroscopy didn't provide as much information because the resulting particle was highly fluorescent. This made it difficult to study pure NX illite and NX illite/M5 mixtures spectroscopically. For those cases, ice identification was determined visually.

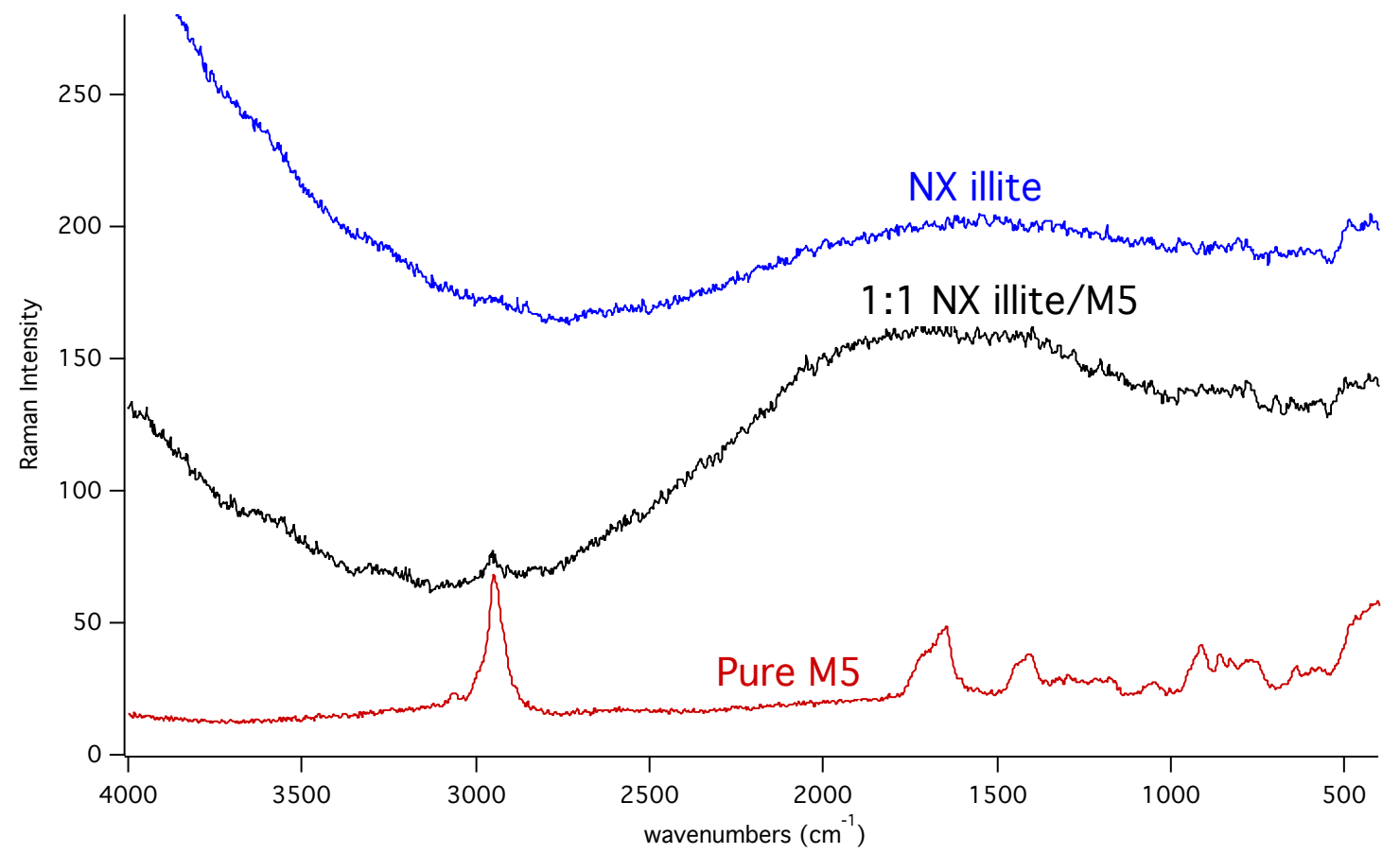

Figure 5. Spectra of different species and mixtures studied. NX illite and mixtures of NX illite with M5 are highly fluorescent making it hard to study spectroscopically. On the other hand, M5 has several signature peaks to help with identification. 


\section{CHAPTER III}

\section{RESULTS}

\section{NX illite}

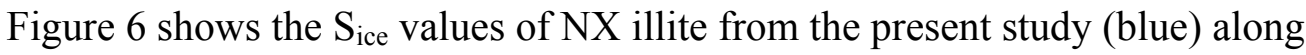
with several literature values. These previous studies were done on pure illite with the exception for Broadley et al. 2012, who studied immersion nucleation of aqueous NX illite. The studies in Fig. 6 are a combination of immersion and depositional freezing. It can be seen that NX illite is an efficient IN with an $S_{\text {ice }}$ value of $1.07 \pm 0.01$ at $-47^{\circ} \mathrm{C}$. However, as the temperature decreases, NX illite's ice-nucleating ability also decreases with an $\mathrm{S}_{\text {ice }}$ value of $1.29 \pm 0.02$ at $-63^{\circ} \mathrm{C}$. The previous depositional ice nucleation studies on pure illite, plotted in Fig. 6, agree well with our study on NX illite, but are at much warmer temperatures and are temperature independent. Previous studies of immersion ice nucleation on illite and NX illite require higher values of $S_{\text {ice }}$ than the depositional ice nucleation of this study. 


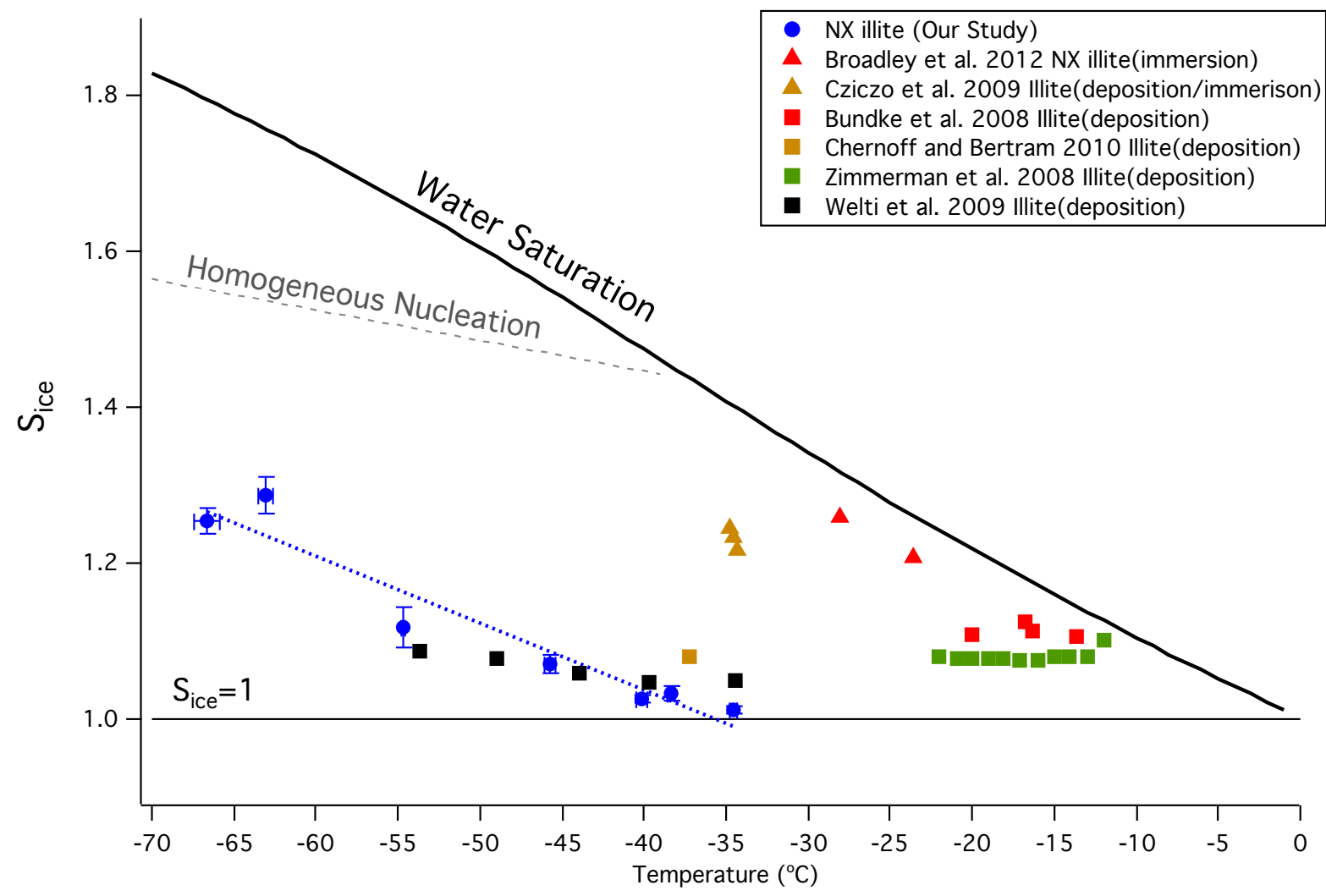

Figure 6. The ice-nucleating ability of NX illite plotted ice saturation ratio vs. temperature. NX illite ice-nucleating ability shows a slight temperature dependence. The points from this study agree well with the pure Illite ice nucleation studies (combination of immersion and depositional freezing experiments).

\section{M5}

Figure 7 shows $\mathrm{S}_{\text {ice }}$ values for pure M5 particles. In contrast to NX illite, pure M5 is a relatively poor $\mathrm{IN}$ with an $\mathrm{S}_{\text {ice }}$ value of $1.30 \pm 0.02$ at $-40^{\circ} \mathrm{C}$ with no measureable temperature dependence. Uncertainty in these values is the calculated standard deviation of multiple experiments. However, M5 is observed to have two different ice nucleation regimes. The image on the left shows ice deposited on the side of the particle, while in the image on the right, shows that the whole particle is frozen. This is suggestive of depositional ice nucleation at low temperature and immersion nucleation at warmer 
temperature. Based on thermodynamic data (Zobrist et al. 2008), M5 should be liquid in the region in which these ice studies are performed so different behavior at low and high temperature was not expected. We then performed water uptake experiments to probe the phase state of M5 under our experimental conditions. Figure 8 shows the temperature/RH trajectories for 4 different experiments. The $\mathrm{RH}$ trajectories began at room temperature (298K). Then while the water vapor content was kept constant, the temperature was decreased to a desired value. The RH was then calculated at each temperature and plotted to show an experimental trajectory. Figure 8 also includes the glass transition line from Zobrist (2008) as well as the homogeneous nucleation line (Koop 2000) and $\mathrm{S}_{\text {ice }}=1$ line.

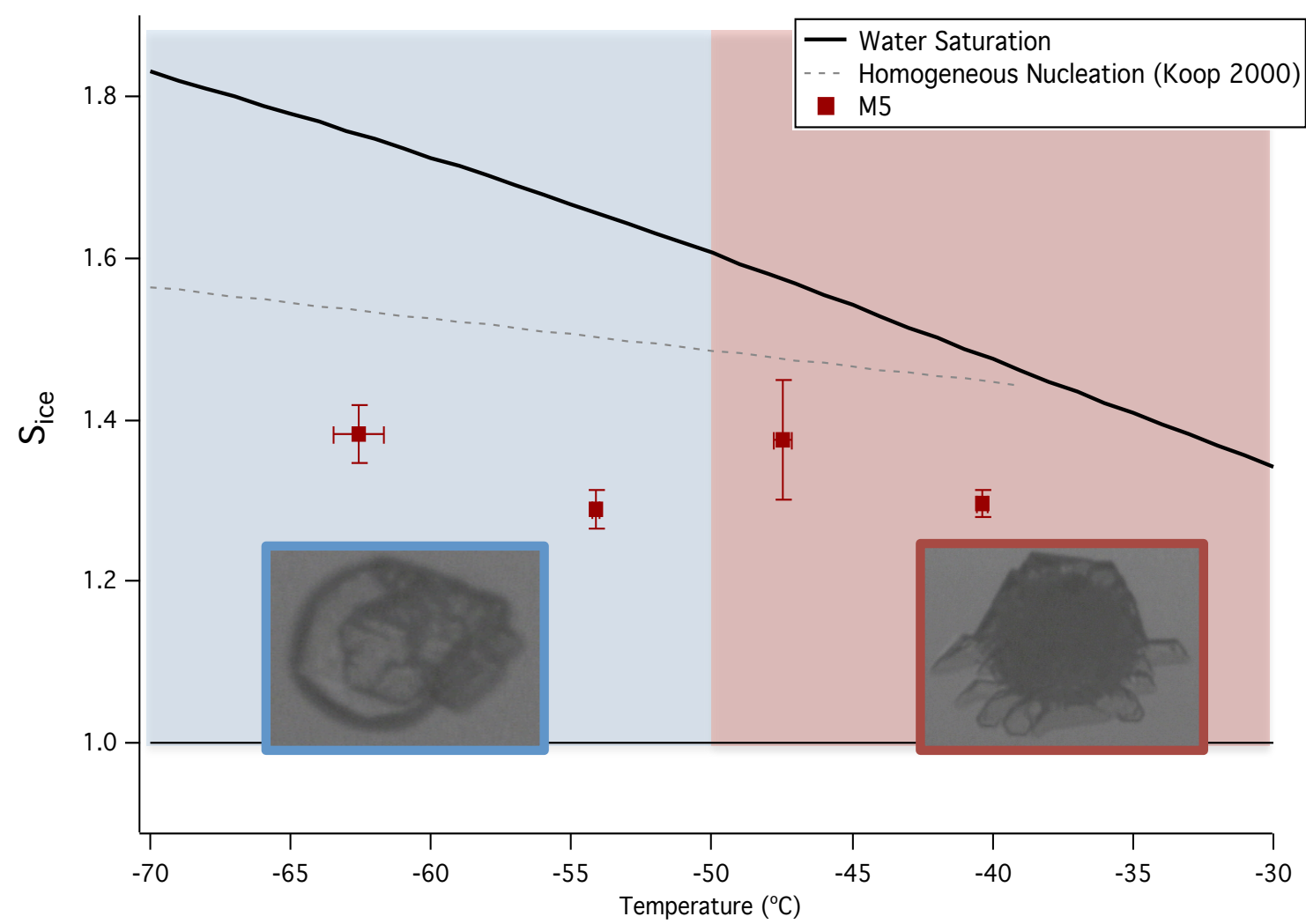

Figure 7. Different ice-nucleating regimes of M5 shown in two different regions. For temperatures less than $-50{ }^{\circ} \mathrm{C}$ (shaded blue), M5 nucleates ice depositionally, as shown in the left image. For temperatures greater than $-50{ }^{\circ} \mathrm{C}$ (shaded red), M5 nucleates ice by immersion, as shown in the right image. 
It can be seen that the M5 particles in the present study are always above the glass transition temperature. However, for the two lowest temperatures, the particles do get close to the glass transition line. In these cases, diffusion may be slow enough and viscosity high enough to favor depositional nucleation over immersion nucleation. To test the idea of diffusion limitation, we measured the growth of pure M5 along the trajectories of Figure 8 and the data are shown in Figure 9. The growth rate is determined as the ratio of wet to dry diameters i.e., $G R=\frac{d_{w e t, R H}}{d_{d r y}}$. Using the imaging program, imageJ, the areas of the particles were sized at each temperature and $\mathrm{RH}$, and the diameters were back calculated.

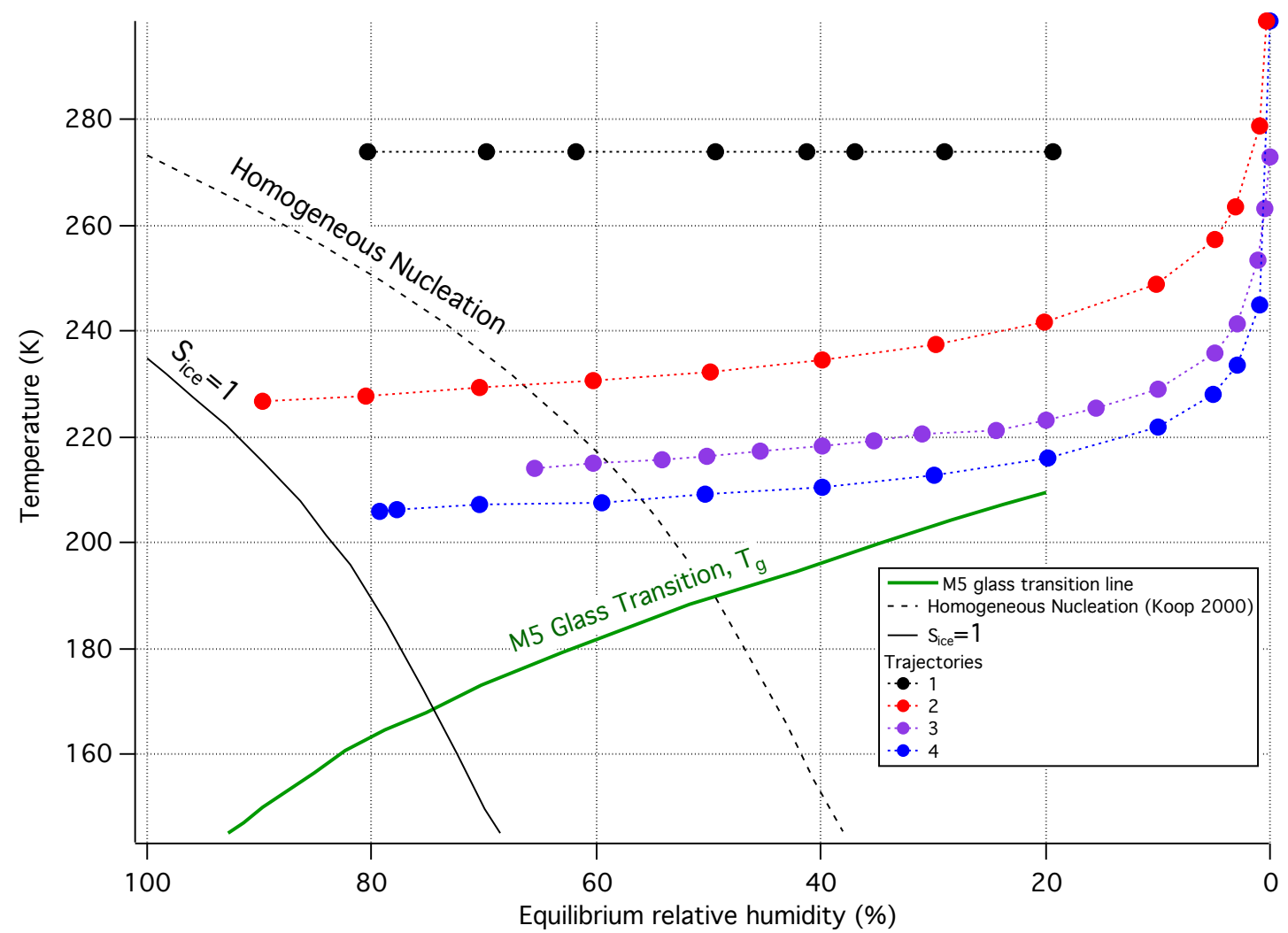

Figure 8. RH/Temperature experimental trajectories for M5. M5 is not always a liquid at all temperatures and thus not glassy here as shown here (Zobrist 2008). Temperature and RH studies of M5 were added to the figure adapted from (Zobrist, 2008) to show that M5 also should not be a glass. 
Figure 9 shows that for the warmer trajectory studies $\left(\right.$ above $\left.-50^{\circ} \mathrm{C}\right)$ the $\mathrm{M} 5$ particles are growing in size due water uptake. This water uptake explains the immersion freezing that is occurring because liquid water is required for immersion freezing. When immersion freezing occurs, the water within the particle freezes and the whole particle becomes frozen (image on right of Fig. 6). In contrast, the colder trajectory studies (below $-50^{\circ} \mathrm{C}$ ) show very little change in diameter as $\mathrm{RH}$ is increased, thus water uptake appears to be inhibited. When a particle is glassy or even semisolid or gel-like, the diffusion of water slows and thus the uptake of water can become negligible. However, when a particle is a liquid, the diffusion of water is fast and the uptake of water becomes significant. We know depositional freezing is occurring at the lowest temperatures because liquid water is not present. When ice freezes depositionally, an ice germ forms on the outside of the particle (image on left of Fig. 6). Also, these colder temperature trajectories are close to the glass transition line suggesting that while a glass hasn't yet formed, a semisolid state may form where diffusion is low and viscosity high, favoring depositional freezing. 


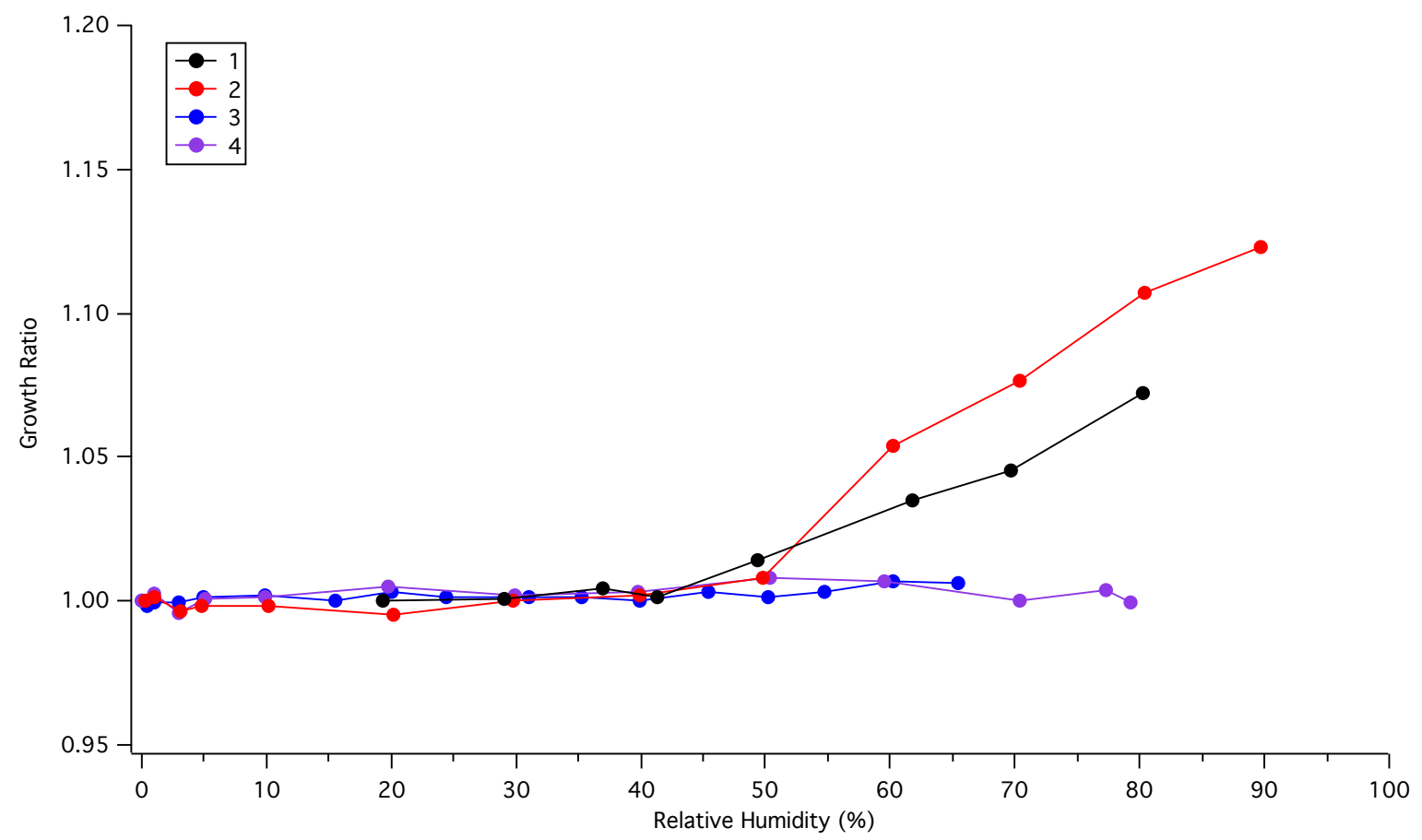

Figure 9. Water uptake by M5. The numbers correspond to the same trajectories that are in Figure 5. The growth ratio is calculated by the diameter growth throughout the RH trajectory.

A study done by Wagner et al. 2012 showed that the ice nucleating ability of glassy aerosol particles could be enhanced over the corresponding liquid phase. Other studies showed that glassy aerosol particles nucleate ice heterogeneously at low supersaturations. (Murray et al., 2010; Wilson et al., 2012). However, work by Schill et al. 2014 found that amorphous semisolid particles simulating secondary organic aerosol (SOA) were poor ice nuclei, with similar $\mathrm{S}_{\text {ice }}$ values as observed here for M5. In the present study, M5 nucleates ice at similar $\mathrm{S}_{\text {ice }}$ values at all temperatures studied, but shows two different nucleation mechanisms. 


\section{NX illite:M5 mixtures}

As mineral dust is transported in the atmosphere, aging will lead to condensation of other species, including organics. To simulate this process ice nucleation was probed on mixtures of NX illite and M5. Figure 10 shows the saturation ratio needed for ice nucleation on the NX illite:M5 1:1 mixture compared to pure NX illite and pure M5. The 1:1 NX illite:M5 mixture has an $\mathrm{S}_{\text {ice }}$ value of 1.30 at $-53^{\circ} \mathrm{C}$ and is temperature independent. It appears to be very similar to ice nucleation on pure M5 and quite different than pure NX illite. To discover the ratio of NX illite:M5 at which the concentration of M5 will hinder the ice nucleating ability of NX illite alone, the ratio of NX illite:M5 was varied from 100:1 to 3:1. Figure 11 shows the results of M5 mixed with NX illite in weight percent ratios stated previously. It can be seen that for NX illite:M5 ratios $>1$, ice nucleation falls on the same line as pure NX illite. In contrast, for NX illite:M5 ratios $<1$, ice nucleation is similar to M5. Thus for all cases, ice nucleation either similar to pure NX illite or pure M5.

Assuming that the particles probed in this study were agglomerates of smaller

particles, the surface area per unit mass of NX illite $\left(104 \mathrm{~m}^{2} \mathrm{~g}^{-1}\right)$ found by Broadley et al. 2012 was used to calculate the number of monolayers $\left(\mathrm{ML}=1 \times 10^{15} \mathrm{molec} / \mathrm{cm}^{2}\right)$ of M5 on NX illite. Densities of 1.6 and $2.7 \mathrm{~g} / \mathrm{cm}^{3}$ were assumed for M5 and NX illite, respectively. It was calculated that when NX illite and M5 of are equal mass (1:1 NX illite:M5) then there are approximately 5 monolayers of M5 on NX illite. For the 3:1, 10:1, and 100:1 NX illite:M5 mixtures, the number of monolayers of M5 are 1.67, 0.50, 
and 0.050 , respectively. This shows that NX illite needs at least 5 monolayers of M5 for M5 to fully inhibit its ice-nucleating ability.

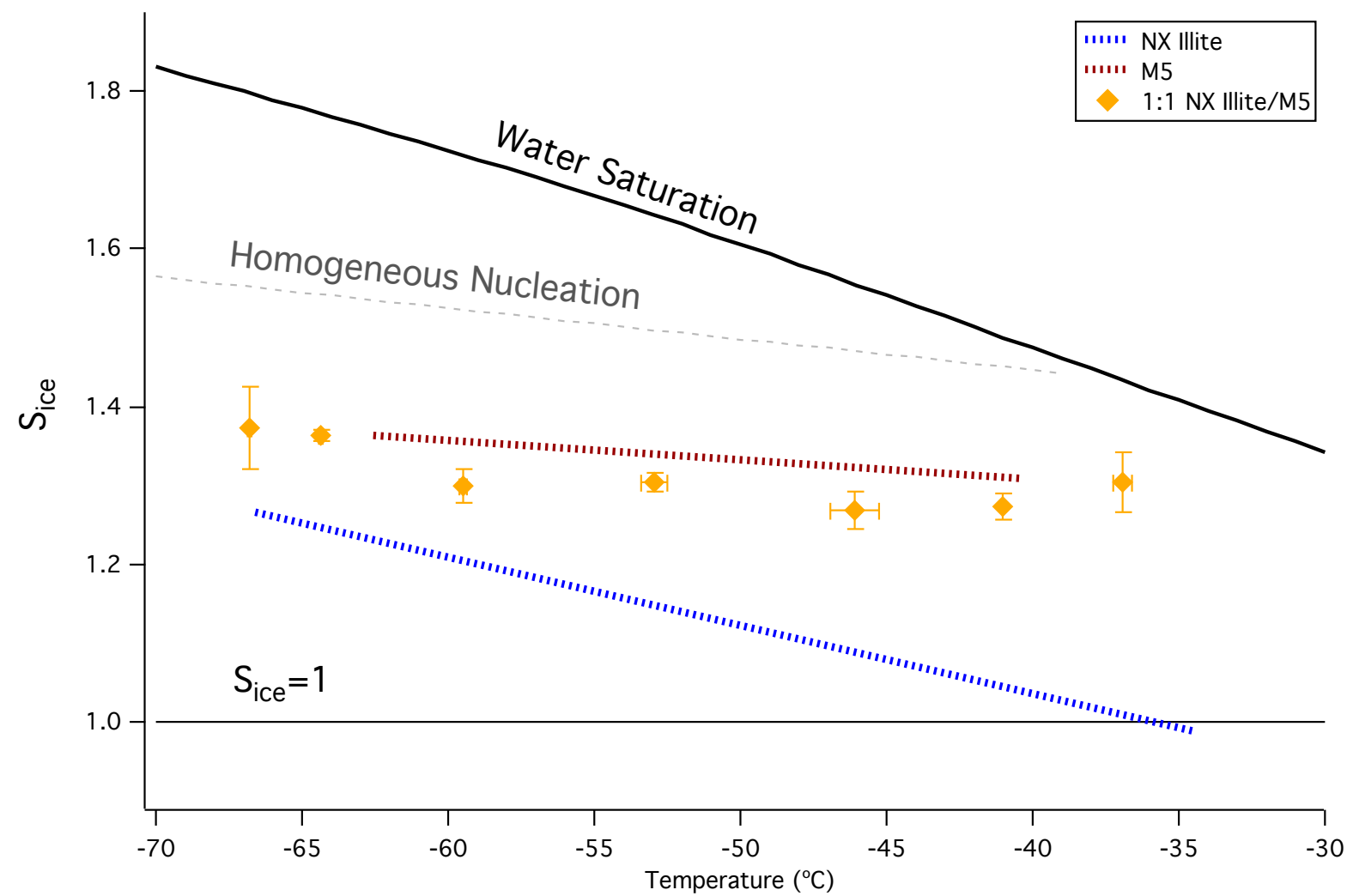

Figure 10. 1:1 NX illite:M5 mixture plotted with pure NX illite and pure M5. A 1:1 NX illite:M5 mixture (yellow) hinders the depositional ice-nucleating ability of NX illite at temperatures above $-60{ }^{\circ} \mathrm{C}$. 


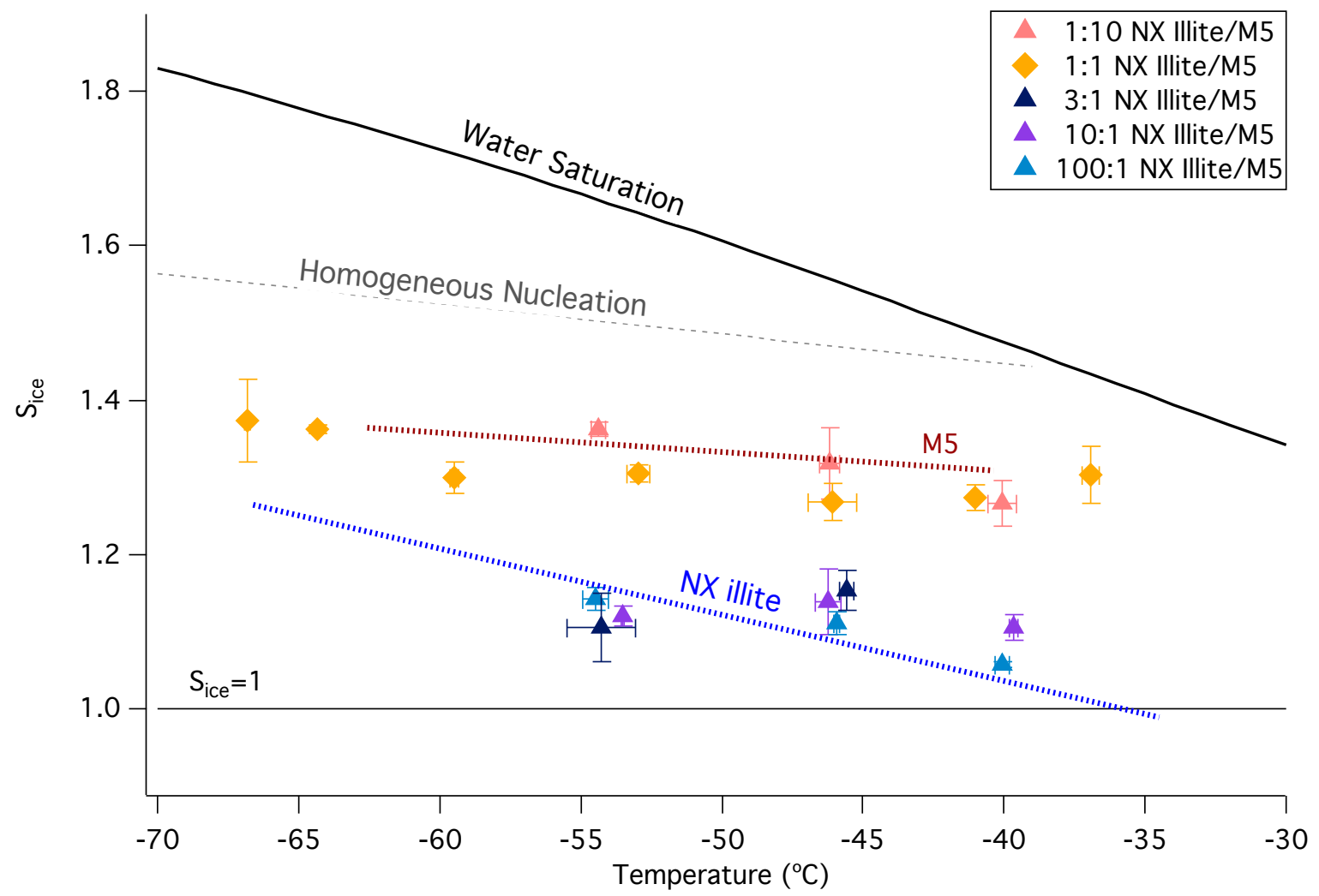

Figure 11. Ice nucleation studies of different ratios of NX illite:M5. Until one obtains a 1:1 NX illite:M5 mixture, there is little-to-no change in the ice-nucleating ability of NX illite. 


\section{CHAPTER IV}

\section{CONCLUSION}

The depositional ice-nucleating ability of NX illite was probed as a function of temperature. The study was done using a Raman microscope outfitted with an environmental cell that allows temperature and relative humidity control. The instrument made it possible to visually and spectrally identify different ice mechanisms as they occurred. NX illite was found to be a good IN with an $\mathrm{S}_{\text {ice }}$ value of $1.07 \pm 0.01$ at $-47^{\circ} \mathrm{C}$; however, ice nucleation on NX illite is slightly temperature dependent with higher $\mathrm{S}_{\text {ice }}$ at colder temperatures. After testing several different NX illite:M5 ratios, it was determined that a 1:1 NX illite to M5 organic coating marked the threshold for hindering the icenucleating ability of NX illite alone (Fig. 10). According to a study done by Cziczo et al. 2013, the majority ( $\sim 90 \%)$ of the ice residuals of cirrus clouds collected were not coated with any sulfate or organic. Thus, it seems unlikely that mineral dust would be coated with an equal weight percent of organic in the atmosphere. Our data thus suggest NX illite under atmospheric condition would be an excellent IN.

At colder temperatures (lower than $-50^{\circ} \mathrm{C}$ ) NX illite:M5 mixtures nucleate ice depositionally, and at warmer temperatures (higher than $-50^{\circ} \mathrm{C}$ ) they nucleate ice by immersion. The ice nucleation mechanisms were determined by studying M5 alone and monitoring its liquid water uptake and growth (Fig. 9). It is clear that at warmer temperatures, the growth of M5 from liquid water uptake is greater than at the colder temperatures. In a study done by Schill and Tolbert 2013, liquid-liquid phase separation occurred in a mixed particle, forming a high molecular weight organic coating around an 
aqueous ammonium sulfate core. This liquid organic coating did not inhibit the icenucleating ability of the ammonium sulfate because the diffusion of water through the liquid organic was fast. In the present study, the organic coating did inhibit the core NX illite. This inhibition could be due to several reasons. First it is possible that diffusion through the M5 organic layer was slow enough to prevent water from reaching the core. Alternatively, the organic coating may have interacted with the surface, deactivating the active sites for nucleation. Finally the organic layer may have filled in cracks or crevices in the agglomerated particles, making these less suitable for ice nucleation.

This study probes the ice-nucleating ability of NX illite, a surrogate for atmospheric dust in the heterogeneous freezing regime. With a better understanding of surrogates of atmospheric dust, we can better deduce the mechanisms underlying the formation of ice clouds, bringing us closer to understanding the effect of ice clouds on climate. 


\section{REFERENCES}

Arnold, E., Merrill, J., Leinen, M., and King, J.: The effect of source area and atmospheric transport on mineral aerosol collected over the north pacific ocean, Global Planet Change, 18, 137-159, 1998.

Aiken, A. and Decarlo, P.: O/C and OM/OC ratios of primary, secondary, and ambient organic aerosols with high-resolution time-of-flight aerosol mass spectrometry, Environ. ..., 42(12), 4478-4485 [online] Available from: http://pubs.acs.org/doi/full/10.1021/es703009q (Accessed 20 November 2014), 2008.

Baustian, K.: Depositional ice nucleation on solid ammonium sulfate and glutaric acid particles, ... Chem. Phys., (2004), 2307-2317 [online] Available from: http:/www.atmos-chem-phys.net/10/2307/ (Accessed 2 May 2014), 2010.

Baustian, K. J., Cziczo, D. J., Wise, M. E., Pratt, K. a., Kulkarni, G., Hallar, a. G. and Tolbert, M. a.: Importance of aerosol composition, mixing state, and morphology for heterogeneous ice nucleation: A combined field and laboratory approach, J. Geophys. Res., 117(D6), D06217, doi:10.1029/2011JD016784, 2012.

Broadley, S. L., Murray, B. J., Herbert, R. J., Atkinson, J. D., Dobbie, S., Malkin, T. L., Condliffe, E. and Neve, L.: Immersion mode heterogeneous ice nucleation by an illite rich powder representative of atmospheric mineral dust, Atmos. Chem. Phys., 12(1), 287-307, doi:10.5194/acp-12-287-2012, 2012.

Bundke, U., Nillius, B., Jaenicke, R., Wetter, T., Klein, H. and Bingemer, H.: The fast Ice Nucleus chamber FINCH, Atmos. Res., 90(2-4), 180-186, doi:10.1016/j.atmosres.2008.02.008, 2008.

Cantrell, W. and Heymsfield, A.: Production of Ice in Tropospheric Clouds: A Review, Bull. Am. Meteorol. Soc., 86(6), 795-807, doi:10.1175/BAMS-86-6-795, 2005.

Chernoff, D. I. and Bertram, A. K.: Effects of sulfate coatings on the ice nucleation properties of a biological ice nucleus and several types of minerals, J. Geophys. Res., 115(D20), D20205, doi:10.1029/2010JD014254, 2010.

Cziczo, D. J., Froyd, K. D., Gallavardin, S. J., Moehler, O., Benz, S., Saathoff, H. and Murphy, D. M.: Deactivation of ice nuclei due to atmospherically relevant surface coatings, Environ. Res. Lett., 4(4), 044013, doi:10.1088/1748-9326/4/4/044013, 2009.

Cziczo, D. J., Froyd, K. D., Hoose, C., Jensen, E. J., Diao, M., Zondlo, M. a, Smith, J. B., Twohy, C. H. and Murphy, D. M.: Clarifying the dominant sources and mechanisms of cirrus cloud formation., Science, 340(6138), 1320-4, doi:10.1126/science.1234145, 2013.

DeMott, P. J., Möhler, O., Stetzer, O., Vali, G., Levin, Z., Petters, M. D., Murakami, M., Leisner, T., Bundke, U., Klein, H., Kanji, Z. a., Cotton, R., Jones, H., Benz, S., Brinkmann, M., Rzesanke, D., Saathoff, H., Nicolet, M., Saito, A., Nillius, B., Bingemer, H., Abbatt, J., Ardon, K., Ganor, E., Georgakopoulos, D. G. and Saunders, C.: Resurgence in Ice Nuclei Measurement Research, Bull. Am. Meteorol. Soc., 92(12), 1623-1635, doi:10.1175/2011BAMS3119.1, 2011.

Dobson, C. M., Ellison, G. B., Tuck, a F. and Vaida, V.: Atmospheric aerosols as prebiotic chemical reactors., Proc. Natl. Acad. Sci. U. S. A., 97(22), 11864-8, doi:10.1073/pnas.200366897, 2000. 
Ellison, G., Tuck, A. and Vaida, V.: Atmospheric processing of organic aerosols, J. Geophys. Res., 104 [online] Available from: http://onlinelibrary.wiley.com/doi/10.1029/1999JD900073/full (Accessed 2 May 2014), 1999.

Froyd, K. and Murphy, D.: Aerosols that form subvisible cirrus at the tropical tropopause, Atmos. Chem. Phys., 209-218 [online] Available from: http://www.atmos-chem-phys.net/10/209/ (Accessed 2 May 2014), 2010.

Koop, T., Luo, B., Tsias, a and Peter, T.: Water activity as the determinant for homogeneous ice nucleation in aqueous solutions, Nature, 406(6796), 611-4, doi:10.1038/35020537, 2000.

Marcolli, C., Luo, B. and Peter, T.: Mixing of the Organic Aerosol Fractions: Liquids as the Thermodynamically Stable Phases, J. Phys. Chem. A, 108(12), 2216-2224, doi:10.1021/jp0360801, 2004.

Murray, B. J., Wilson, T. W., Dobbie, S., Cui, Z., Al-Jumur, S. M. R. K., Möhler, O., Schnaiter, M., Wagner, R., Benz, S., Niemand, M., Saathoff, H., Ebert, V., Wagner, S. and Kärcher, B.: Heterogeneous nucleation of ice particles on glassy aerosols under cirrus conditions, Nat. Geosci., 3(4), 233-237, doi:10.1038/ngeo817, 2010.

Richardson, M. S., DeMott, P. J., Kreidenweis, S. M., Cziczo, D. J., Dunlea, E. J., Jimenez, J. L., Thomson, D. S., Ashbaugh, L. L., Borys, R. D., Westphal, D. L., Casuccio, G. S. and Lersch, T. L.: Measurements of heterogeneous ice nuclei in the western United States in springtime and their relation to aerosol characteristics, J. Geophys. Res., 112(D2), D02209, doi:10.1029/2006JD007500, 2007.

Schill, G., Haan, D. De and Tolbert, M.: Heterogeneous ice nucleation on simulated secondary organic aerosol, Environ. Sci. .. [online] Available from: http://pubs.acs.org/doi/abs/10.1021/es4046428 (Accessed 20 November 2014), 2014.

Schill, G. P. and Tolbert, M. a.: Heterogeneous ice nucleation on phase-separated organic-sulfate particles: effect of liquid vs. glassy coatings, Atmos. Chem. Phys., 13(9), 4681-4695, doi:10.5194/acp-134681-2013, 2013.

Welti, A. and Lüönd, F.: Influence of particle size on the ice nucleating ability of mineral dusts, ... Chem. Phys., 6705-6715 [online] Available from: http://www.atmos-chem-phys.net/9/6705/ (Accessed 17 September 2014), 2009.

Wilson, T. W., Murray, B. J., Wagner, R., Möhler, O., Saathoff, H., Schnaiter, M., Skrotzki, J., Price, H. C., Malkin, T. L., Dobbie, S. and Al-Jumur, S. M. R. K.: Glassy aerosols with a range of compositions nucleate ice heterogeneously at cirrus temperatures, Atmos. Chem. Phys., 12(18), 8611-8632, doi:10.5194/acp-12-8611-2012, 2012.

Zimmermann, F., Weinbruch, S., Schütz, L., Hofmann, H., Ebert, M., Kandler, K. and Worringen, A.: Ice nucleation properties of the most abundant mineral dust phases, J. Geophys. Res., 113(D23), D23204, doi:10.1029/2008JD010655, 2008.

Zobrist, B. and Marcolli, C.: Do atmospheric aerosols form glasses ?, Atmos. Chem. Phys., 5221-5244 [online] Available from: http://www.atmos-chem-phys.net/8/5221/2008/acp-8-5221-2008.html (Accessed 2 May 2014), 2008. 